\title{
The Importance of Relationships for the Produced Knowledge in the Sector of Management Consulting
}

\author{
R. Lopes da Costa, Filipa M. Tavares \& Maria I. Miguel \\ ISLA Santarem, Portugal
}

Received: Jan. 26, 2013 Accepted: February 28, 2013 Published: April 1, 2013

doi:10.5296/jmr.v5i2.3147

URL: http://dx.doi.org/10.5296/jmr.v5i2.3147

\begin{abstract}
While the management consulting industry has been largely linked to the knowledge produced within the disciplines of strategic management in the academic field, the truth is that very little literature is produced in terms of research in this area, while the researchers focused more on a set of static techniques to be applied in the development of this field of research concerns. This article seeks to bridge this gap as well, showing by example that the consultancy sector is a true field of opportunities for the study of relationships management. This presentation is thus the aim of contributing both theoretically and empirically in the area of relationships through research in the context of management consulting, trying to visualize how the relationships are manifested in a context of high involvement and personal contact, and what's the perception that must be taken into consideration by clients and consultants in terms of the benefits of their greater or lesser degree of involvement.
\end{abstract}

Keywords: Management Consultancy, Relationships, Knowledge 


\section{The Consulting Industry}

The increasing pressure from the markets, characterized by the intense competition and instability leads organizations and people to rethink their strategies in dealing with the other parties. As organizations will be guided to their central areas (core business), freeing themselves form areas / activities that they do not dominate, the dependence on external sources of supply increases (Lopes da Costa, 2009).

The complexity and instability expressed here undoubtedly describes the thought of Bruce Henderson (1979), the creator of the consultancy BCG (Boston Consulting Group), based on the assumption that the business world is a true natural selection, as it exists in the animal world, where the focus should be primarily directed to a good understanding of the natural context (surrounding).

Organizations are analyzed from this point of view in a economic, political, organizational and individual perspective, where the free market and customer are fundamentally domain focused in terms of social relations (Du Gay, 2005) and as a portfolio development, employment contract, domestic markets, outsourcing and organizational imperative change continue to dominate organizational research worldwide (Barley \& Kunda, 2004; Beer \& Nohria, 2000).

According to Canback (1998), these fields of the domain of the management which are the evolution of strategic subjects in the organizations and have been largely disseminated by the management consulting sector, describing the sector as a path of success that should be embraced by companies in the context of their strategic direction and professionals as the true disseminators of the complex phenomenon of business evolution known today.

However, although it is considered that the activities of management consulting have obtained a considerable growth in terms of economic significance in recent years (Fincham \& Clark, 2002) which consequently should have been translated into further research in this sector, truth is that these results have not been properly followed up with studies focusing on the level of relationships that are created and established between the parties involved in this process, considered by Nikolova, Reihlen and Schlapfner (2009), Karantinou and Hogg (2001, 2009), Fincham $(1999,2003)$ and Sturdy (1997) as a key factor of success in the development of projects in this sector.

In other words, even if we have into account the ambivalent status of consultants and their own failures that eventually could have been known at the level of the industry created in the meantime, this is and will remain an important sector of study and management of all their structural composition, particularly in terms of the study of relationships, because according to Fincham (2010) and Armbruster (2006), these can even function as the true strength of corporate power, the lever of organizational and economic change and, a true development source of ideas.

\section{The Main Stages of a Consulting Project}

Although the main goal of this article intends to look into the roles that must be assumed by 
clients and consultants regarding the establishment of successful relationships between the parties and on the consequent radical changes in the nature of these so that they are able to reach these same goals, it seems pertinent to address first beforehand base assumptions of consulting activity, this study by Nikolova et al. (2009), adjusts this component to the summarized identification of four stages of a consultation process - Figure 01.

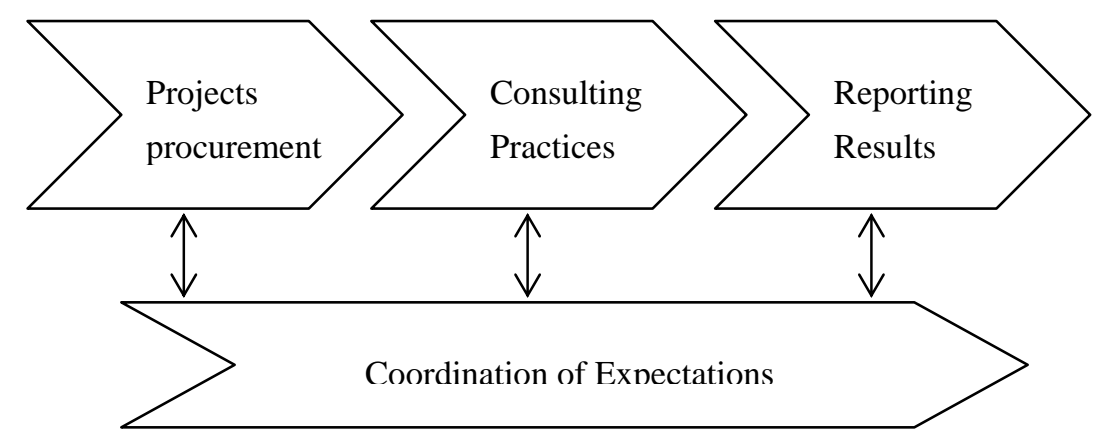

Figure 1. Main Stages of a Consulting Project

Source: Nikolova et al. (2009)

According to Nikolova et al. (2009) the procurement of projects is the first step of the consulting process. It is at this stage therefore that the skills of rhetoric persuasion are enhanced and often identified in the literature of this area.

Although the management consulting industry has become incredibly competitive and the emphasis from customers referrers to increasingly higher levels of expectation in terms of performance evaluation (Nikolova et al., 2009), indeed this stage still remains implicit in a skeptical view of analysis where the consultants continue to claim to them the role of "experts" and where the dependency factors, recognition and legitimacy take itself particularly prominent factor regarding scientific objectivity (Alvesson, 2001).

From the results presented by Nikolova et al. (2009), this step is based directly on the "critical model" analysis of built relationships between consultants and clients, i.e., named the "system of persuasion" by Alvesson (1993). In this model the consultant takes the lead by creating conditions for a controlled position and a positive management image (Fincham \& Clark, 2002), which portrays the client as a vulnerable and passive victim regarding these rhetorical skills and competencies (Kieser, 2002; Alvesson, 2001; Bäcklund \& Werr, 2001; Jackson, 2001; Salaman \& Clark, 1996; Clark, 1995). Rhetoric, metaphors (Greatbach \& Clark, 2002), ambiguity and vague knowledge of business (Nikolova et al., 2009) are factors that characterize this model against the insecurities and fears of customers.

After the pre-stage of the process, according to Nikolova et al. (2009) we must go to the consulting activity itself, which, according to the authors can take of two types: "feline" and "exploratory" consulting. The exploratory consulting refers to the development of innovative 
projects where customers clearly demonstrate a lack of substantive and methodological knowledge to assist consultants in diagnosing problems and developing methods to solve them. In this case the critical factor is not at all the transfer of expertise, but the support offered to the client in structuring the resolution of the problem through specific aid reflected in a set of high involvement interactive techniques and intensive learning between clients and consultants, which creates a positive image of consultants rather than reflecting the ambiguity referred previously.

The equitable balance of the relationship mentioned here, called by Nikolova et al. (2009) as "social learning model" thus present the consultant's role as a facilitator and trainer, from the diagnosis of the problem, the generation of alternatives, evaluation of those alternatives and their implementation, to be part of a process driven by both actors.

This perspective emphasizes also the third view of relationships of consultants by Styhre and Werr (2002) where the consultant can act as an internal subordinate on the control of the organizational manager (bureaucratic and functionalist image of relationships - see Kurb, 1996, Greiner and Metzger, 1983), while holding the necessary autonomy that must be contained in the base characteristic of an external expert to the organization (vision model or critical), functioning as a fellow manager in an attempt to discern practices and strategic models that enable the development of an organizational proactively.

However, in contrast with innovative designs projects, there are those based more routinely called by Nikolova et al. (2009) as "feline consulting". In this case, both procedures can be considered, an associate with the assumption that the action of consultants consists in solving concrete problems with the help of scientific theories and techniques, being seen as "experts" and holding a position of relative superiority and power regarding the customers - "expert model", and another that incorporates the involvement of high strategic relevance of projects. In the latter case the involvement of customers is of vital importance, especially in the case of clients with extensive experience and knowledge relevant to this matter, whose participation takes increasing procedural efficiency factor to be incorporated in the revolution of problems. Here again, there is the assumption of the consultant as a facilitator and the client as part of the process and not as mere transmitter of information, which reflects again the social model of learning (Styhre \& Werr, 2002; Schein, 1999). Table 01 summarizes the basic assumptions associated with the practice of consulting activity: 
Table 1. Base Assumptions Consultancy Activity

\begin{tabular}{|c|c|c|c|c|}
\hline $\begin{array}{l}\text { Based approaches } \\
\text { of consulting } \\
\text { relationships }\end{array}$ & 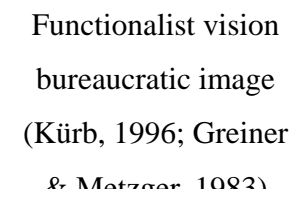 & \multicolumn{2}{|c|}{$\begin{array}{l}\text { Critical view } \\
\text { Fincham e Clark, 2002; Backlund } \\
\text { \& Werr, 2001; Clark \& Salaman, } \\
\text { 100द. Clnrl, 100๔ }\end{array}$} & $\begin{array}{l}\text { Integrative approach } \\
\text { (Werr \& Styre, 2002) }\end{array}$ \\
\hline Relationships of & $\begin{array}{l}\text { Client as "element in } \\
\text { control of the } \\
\text { develnnment nroresc }\end{array}$ & $\begin{array}{l}\text { Consultant with a } \\
\text { management and } \\
\text { customer as vul } \\
\text { rhetnrical ckills al }\end{array}$ & $\begin{array}{l}\text { positive image of } \\
\text { position control, } \\
\text { arable victim of } \\
\text { rnmnetenries of }\end{array}$ & $\begin{array}{l}\text { Working together where } \\
\text { the consultant takes a } \\
\text { suhnrdinate and }\end{array}$ \\
\hline $\begin{array}{l}\text { The three models } \\
\text { of } \\
\text { consultant-client } \\
\text { intorartion hv }\end{array}$ & & $\begin{array}{l}\text { "Expert Model”- } \\
\text { Aharoni, 1997; } \\
\text { Kürb, } \quad 1996 ; \\
\text { Sadler, 1988; }\end{array}$ & $\begin{array}{l}\text { “Critical Model” } \\
\text { - Kieser, 2002; } \\
\text { Alvesson, 2001; } \\
\text { Jackson, 2001; }\end{array}$ & $\begin{array}{l}\text { "Social Learning Model" } \\
\text { - Lilja \& Poulfelt, 2001; } \\
\text { Schein, 1999; McGivern, }\end{array}$ \\
\hline Relationships & & 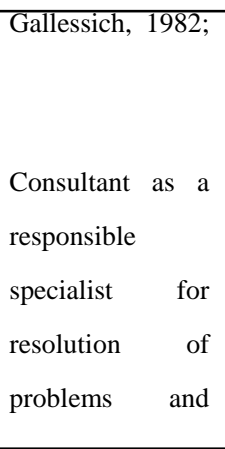 & $\begin{array}{l}\text { Clark \& Salaman, } \\
\text { Consultants as } \\
\text { ambiguous, } \\
\text { vague and } \\
\text { rhetorical, which } \\
\text { portrays } \\
\text { customers as }\end{array}$ & $\begin{array}{l}1983 \\
\text { Consultants as facilitators } \\
\text { and clients as part of the } \\
\text { diagnostic process, } \\
\text { generation of alternatives, } \\
\text { evaluation of those } \\
\text { alternatives and their }\end{array}$ \\
\hline Key concepts & $\begin{array}{l}\text { Consultant as assistant } \\
\text { Client as "element in } \\
\text { rontrnl }\end{array}$ & $\begin{array}{l}\text { Consultant as } \\
\text { dominant actor } \\
\text { rinctomor ac }\end{array}$ & $\begin{array}{l}\text { Consultant as } \\
\text { ambiguous, } \\
\text { rhetorical, vague } \\
\text { Customer as } \\
\text { vulnerable victim }\end{array}$ & $\begin{array}{l}\text { respective } \\
\text { Consultant as a facilitator } \\
\text { and trainer } \\
\text { Customer as part of the } \\
\text { development process }\end{array}$ \\
\hline
\end{tabular}

Source: Elaborated by the Author

The third step of the process or the post-project phase is directly linked to communication of results. The presentation of results is the final phase of the consulting project, although this does not mean that it is less important. In order to compare the results with the originally agreed in terms of reference, the key interventions of consultants can be summarized into three factors, help managers in the interpretation of results, work the creation of these perceptions and, most importantly, engage and shape them as to know how they should 
communicate the results to senior management, supporting this transfer of knowledge with adequate skills to meet the success with this same task.

The dynamic interaction between clients and consultants therefore results in the fourth stage of the project, the process of coordination of expectations. According to Nikolova et al. (2009) this action is the final stage of the procedural chain of the different chapters of a consulting process, although according to the authors it is a horizontal task performed during the whole project from the beginning to its end. In truth the higher expectations are placed, the higher the risk of disappointment when the results that may be obtained are given. Here, although consultants and clients can work together in the diagnosis and solution of a given problem it does not mean that the result cannot aim towards disappointment in some of the parties involved. That is, the coordination of expectations thus assumes a role of extreme importance in the process, involving not only the existence of constant negotiations, but also for the unique opportunity that it offers to advisors in terms of laying the foundations of trust that might be obtained with clients and may come to regenerate into future projects.

\section{Relationships Dynamics of Consultant-Client}

Exploring the interaction between consultants and clients in the different ways they relate and taking into account the set of readings, ideas, approaches and interpretations taken by several authors in describing the functionalist and critical perspective, which can be observed is that there is a clear analysis void concerning the development of this area, this is because in theory a manager does not need to be limited by choosing between the advisor as superior or subordinate, a manager should consider that, whenever possible, equal powers are an effective alternative between parties in the development of different types of projects.

This point of view will not in any way withdraw the importance of contextual functionalist and critical approaches, because it is an indisputable fact that both were an important landmark in the positioning of the understanding the consultant-client relationship, what this adds is a more situational and contingent perspective compared to what they confirm by these two proposed images (Fincham, 1999; Sturdy, 1997), this may be because such approaches neglect important structural and contingency factors with significant impact on the relationship between consultant and client.

Taking as an example the functionalist perspective described by Schein (1999) in which feelings are essentially linked to cultural factors in a given period and space, the critical perspective vision by Kipping (2002) and Fincham (1999) in which it is suggested that relationships may vary in space and time through institutional ideas of management nature and image and management consulting, such as the borders and the division of labor between perceived problems in the day-to-day basis by companies and managers, Werr and Styhre (2002) emphasize here the importance of ideas and institutional practices - called speeches by the authors - as an important factor to consider in the consultant-client interaction.

According to the perspective of Styhre and Werr (2002) instead of considering only an interpersonal basis, the consultant-client relationship emerges like a relational game between different characteristics of a given specific situation between actors, without there being a 
pre-defined role in terms of nature of both sides. The relationship thus results in the development of mutual activities in dependent situations and contexts, which goes to the mismatch of certain management speeches that determine the legitimate nature of relationships.

Here, although the boundaries of speech are difficult to determine, Styhre and Werr (2002) used the bureaucratic dichotomy of the bureaucratic organization vision of Du Gay (2005) and networking of Lopes da Costa (2010) as a model of theoretical analysis to the issue of relationships built between consultants and clients. That is, contextualizing the theme starting from the theorized bureaucratic speech in the 1940s and 1950s by Max Weber and Taylor (characterized by routines, standardized operating procedures and manuals based on a clear separation between manual and brain work, where the manager controls the entire organization of the company) to the knowledge society or network society (where change and flows are constant threats to the business, being the routines and standard procedures in constant organization process and redesigned to allow companies a better adaptation to constant influences of the external environment - the control is low priority, and the leitmotiv is leadership, training, support and business sense) both perspectives are considered as intrinsic aspects in various management practices, because these are the ones that actually force the client-consultant relationship to flow in different directions and opposite ways.

From this idea and according to Styhre and Werr (2002) the functionalist and critical approach can be considered simultaneously, because on one hand there is the need to seek answer to a contemporary style of business in practical terms, on the other hand, it is also necessary in this context a bureaucratic rationality of the process, based on monitoring and the management.

It follows then, from the works of Styhre and Werr (2002) a third vision or perspective. The work carried out by the authors in several experiments and studies with consultants and especially in the research carried out in two Swedish telecommunications organizations, led them to realize that both situations can be ensured and often simultaneously, because, in the same studies the bureaucratic concepts are described in longed relationship that is wanted, the same way we know beforehand that the concepts of networking describe the current use of consultants.

Thus, and as suggested by Werr and Styhre (2002) the customer can switch between the view of the consultant as part of the organization and at the same time be aware of the clear cut of the paper of management in the relationship. In this perspective, the consultant can act as a internal subordinate under control of the organizational manager (bureaucratic image), while holding the necessary autonomy that must be contained in the base characteristic of an external expert to the organization, working as a manager's colleague in an attempt to glimpse practices and models that enable strategic organizational development in a pro-active way. The client will therefore develop an ambivalent attitude that allows keeping an "in control" role while creating a clear dependence of the next work of the consultant. 


\section{Macrothink \\ Journal of Management Research \\ ISSN 1941-899X \\ 2013, Vol. 5, No. 2}

\section{Interactions and Relationships Conceptual Structure}

It is generally agreed that the consultants are in the business of creating knowledge, but the truth is that many act just as suppliers of ideas which leads to that many business managers view them as experts and base the relationship on an approach of dominance and dependency.

An important alternative to this kind of dependency is therefore the resistances that may be made by managers in implementing efficient business practices on the part of these professionals in their organizations. That is, the role of the management consultant in an organizational processes must provide not only the strategic perspective linked to consulting practices and its implementation in an attempt to solve experienced problems in the organizational activity (Clark, 1995; Schein, 1988), but also one structural perspective (focused on the constant changes of the international economy) that requires cooperative changes in various contexts.

The perfect approach, so goes by the complementarily of these two perspectives, and should be considered together in the identity of the consultants themselves. Yet it is important to realize that none of this disables that the consultant-client relationship should be asymmetric, on the contrary, the balance of power should always when possible remain equitable and cooperative, and be powered by networking allowing beneficial gains for both parties, allowing to obtain a mutual learning among different actors by sharing different mental structures combined with the variety of methods and technical concepts presented by professional consulting.

However, in order to better illustrate the perception about the study of relationships, Karantinou and Hogg (2001) designed with great effectiveness, for this purpose, a conceptual framework of interactions and relationships. Following their theory this structure can be subdivided into three distinct axes; influence factors, the actors and resulted interactions and relationships (Figure 02). 


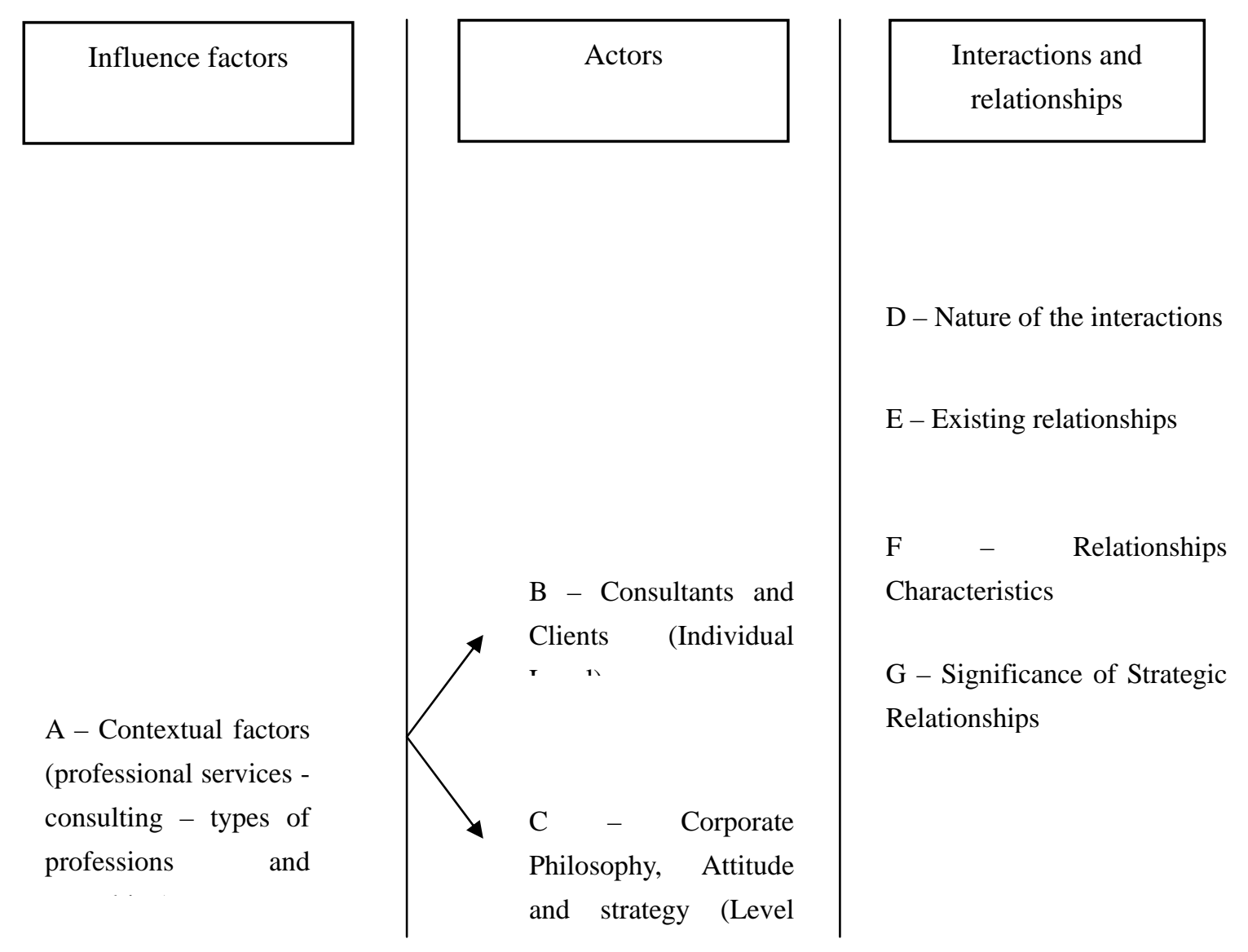

$\mathrm{H}$-Benefits and Costs for the Consultants

I - Benefits and Costs for the Clients

Figure 2. Conceptual Structure of Interactions and Relationships

Source: Karantinou and Hogg (2001)

The first part of the conceptual framework involves the influential factors related to the characteristics of relationships with its utility, paths and trails to be followed by the actors. At this level it is important to disentangle the different consulting contexts, and these are related to the different types of professional services involved and / or with their own types of work of the same industry (strategic, operational, IT, marketing) and they may require different levels of interaction and relationship between the parties in building a cooperative structure and ease the development of effective projects. 
The second part of the structure relates to actors, either in individual or collective terms. At a collective level it will be important to understand how relationships may or may not be affected by the philosophy of the companies, by their behaviors, attitudes and strategies. Likewise it is important to make an identical assessment to the actors in single issues, particularly regarding their beliefs, choices and actions that determine the existence and significance of relationships in an attempt to firstly understand how the consultants see, act and manage different types of relationships and, secondly, to understand the perception of loyalty and relationships that are taken into consideration by customers.

Finally, we have the third part of the conceptual framework, whose perspective refers to the nature of the interactions themselves, to the existence and characteristics of relationships and the costs and potential benefits of these same relationships as a result of the active participation of the actors (consultants and customers). It is from this same analysis that it is easily found that management consulting has a completely different role in the complex phenomenon involving the different characteristics of relationships. Otherwise consider. Contrasted with the traditional view of marketing relationships aimed primarily to "purchase" and regular maintenance of customers that are part of active organizational support through retention, duration (long term bonds) and productivity, the consultant relationships operate mainly in the context of "business to business", where the main focus is not in relationships, but in the way companies deal with these same relationships.

In contrast to the approach of traditional marketing relationships, where there is an active seller and a passive buyer, the consulting relationships are more like the marketing approach of the IMP (International Marketing and Purchasing) whose relationships must be built from two parties, and both have an active role in their development. Thus, the relationships do not happen they are searched from appropriate strategies and methods and well selected techniques, building "win-win" relationships where both are active players in the of building long-term relationships.

It may be said that relationships can be used in a variety of ways. What is right is that not always the business interactions can manage different types of relationships that can arise as a result of these same interactions, nor the retention itself means a relationship. That is, although different studies address different views about relationships in consulting, this approach is not taken for granted and or finalized, and its development will always be compared to other views on this matter to enable a better understanding of marketing and consulting relationships and that build multiple perspectives and hypotheses by comparing these three different factors (influencing factors, actors and interactions and relationships) in the analysis.

In this sense, it is important to clarify a number of issues that regenerate the previously presented conceptual framework, such as the nature of the interactions, which are the characteristics of relationships, which attitudes, philosophies and strategies of consulting companies regarding management relationships, which customers view and what benefits and costs of managing relationships are associated to consulting companies and customers (Karantinou \& Hogg, 2001). 
On the other hand, by reading Karantinou and Hogg's (2001) work it highlights the need, namely, the importance of an accurate analysis of the costs and benefits associated with the development of long-term relationships, because despite its advantages, there are also significant disadvantages associated with long-term connections that must also be taken into account. These chain of disadvantages can include the loss of excellent business opportunities, the extreme dependence of certain customers, the loss of the external perspective, boredom, stagnation (Karantinou \& Hogg, 2001) and staff turnover resulting from these same constraints, being that new customers may result in freshness and invigoration of the operational plan and the motivation of the staff (Maister, 1982).

On the other side of the chain, the customer's prospective reflects similarly the same results. Although they have different interpretations about quality and not everyone is interested in long-term relationships, the studies of Karantinou and Hogg (2001) found that two of the main factors that must be demonstrated by the consultants in building long-term relationships are empathy and honesty, although some customers fear that often the main concern of these may be related to retention of clients for long-term dependency, diminishing the main aim of concern, the need to offer effectively different solutions and efficiency.

\section{Final Remarks}

For all these reasons, it is concluded therefore that the nature of consulting interactions as in most of any social interaction reflects a complex process that operates in the power between very sensitive scales often given by the different perceptions and goals that are in the foundation of the assessment of each participant (consultant and client). Gummesson (1996) demonstrates this same complexity based in the little clarification even of the boundaries that should exist between these same parties, resulting sometimes in conflicting processes of no return.

That is, the important thing here is that both parties have a clear perception of what it means quality of service and that although a consulting job means working together in the field of diagnosis and the development of measures, there is a clear perception of any of these parts at the border that both must comply, so that neither the consultant becomes part of the organization, nor the organization takes over the work performed by the consulting firm and its professionals (Gumesson, 1996). Thus, the consultant must spend most of the time on homework and developing methods and practices that may achieve fruitful results in the future, dealing with the interactions carefully in order to build a framework of trust that gradually develops into building relationships that referring to long-term bonds (Karantinou \& Hogg, 2001).

That is, the important thing is to emphasize the importance of the characteristics of relationships that are the foundation of success, but for that we must build structures to obtain similarities between trust and organizational philosophies to achieve lasting relationships and added value in finding the best strategy for the identified problem, regardless of the disciplines, people or groups that engage, even because as estimated by the newspaper Economist (Economist, 1997) 60\% to 70\% of projects in the area of consulting management services are due to repeated work carried out by lasting connections between organizations. 
To sum up, it is important to extend this study as an investigative and reflective basis, there is a need to deepen and explore in the future the nature and quality of relationships in an attempt to achieve even higher quality results, whether they are linked to cases of success or the consulting processes characterized by failure. On the other hand, it is here also encouraged to further explore the different types of relationships in consulting and the possible development of these throughout the process of knowledge transfer between consultants and clients, in order to diagnose customers' interests and how the respective strategies that lead to success can be outlined, with mutual benefits for both parties.

\section{Bibliography}

Alvesson, M. (1993). Organizations as Rhetoric: Knowledge-Intensive Firms and the Struggle with Ambiguity. Journal of Management Studies, 30(6), 997-1015. http://dx.doi.org/10.1111/j.1467-6486.1993.tb00476.x

Alvesson, M. (2001). Knowledge Work: Ambiguity, Image and Identity. Human Relations. Vol. 54, No 7, pp. 863-893. http://dx.doi.org/10.1177/0018726701547004

Armbruster, T. (2006). The Economics and Sociology of Management Consulting. Cambridge University Press, Cambridge. http://dx.doi.org/10.1017/CBO9780511488467

Backlund, J. \& A. Werr (2001). The Construction of Global Management Consulting - A Study of Consultancies Web Presentations. SSE/EFI Working Paper Series in Business Administration, 3, 1-30.

Barley, S. R. \& G. Kunda (2004). Gurus, Hired Guns and Warm Bodies. Princeton University Press, Princeton, NJ.

Beer, M. \& Nohria, N. eds (2000). Breaking the Code of Change. Harvard Business School Press, Boston, MA.

Canback, S. (1998). The Logic of Management Consulting (Part One). Journal of Management Consulting, 10(2), 3-11.

Clark, T. (1995). Managing Consultants - Consultancy as the Management of Impressions. Open University Press, Buckingham

Clark, T. \& Salaman, G. (1996). The management Guru as Organizational Witchdoctor. Organisation Studies, 3(1), 85-107.

Dugay, P. (2005). In Praise of Bureaucracy. Sage, London.

Fincham, R. (1999). The Consultant-Client Relationship: Critical Perspectives on the Management of Organizational Change. Journal of Management Studies, 36(3), 335-352. http://dx.doi.org/10.1111/1467-6486.00139

Fincham, R. (2003). The Agent's Agent: Power, Knowledge and Uncertainty in Management Consultancy. International Studies of Management and Organization, 32(4), 67-86.

Fincham, R. (Forthcoming) (2010). The client in the client-consultant relationship. Em T. 
Clark and Kipping (eds). The Oxford Handbook of Management Consultancy. Oxford University Press.

Fincham, R. \& Clark, T. (2002). Preface: Management Consultancy - Issues, Perspectives and Agendas. International Studies of management and Organization, 32 4), 3-18.

Greatbach, D. \& Clark, T. (2002). Laughing with the Gurus. Business Strategy Review, 13(3), 10-18. http://dx.doi.org/10.1111/1467-8616.00217

Greiner, L. \& Metzger, R. (1983). Consulting to Management. Prentice-Hall, Englewood Cliffs, N.J.

Gummenson, E. (1996). Relationship Marketing and Imaginary Organisations: A Synthesis. European Journal of Marketing, 30(2),.31-44. http://dx.doi.org/10.1108/03090569610106635

Henderson, B. (1979). Henderson on Corporate Strategy. Abt Books, Cambridge, Mass.

Jackson, B. (2001). Management Gurus and Management Fashions. A Dramatistic Inquiry. Routledge, New York.

Kieser, A. (2002). Managers as marionettes? Using fashion theories to explain the success of consultancies. Em Kipping \& Engwall (eds.). Management Consulting-Emergence and Dynamics of a Knowledge Industry. Oxford University Press, New York, Oxford.

Karantinou, K. \& Hogg, M. (2001). Exploring Relationship Management in Professional Services: A Strudy of management Consultasncy. Jornal of management Marketing, 17, 263-286.

Karantinou, K. \& Hogg, M. (2009). An Empirical Investigation of relationship development in professional business services. Journal of Services marketing, 23(4),249-260. http://dx.doi.org/10.1108/08876040910965584

Kipping, M. (2002). Trapped in Their Wave: The Evolution of Management Consultancies. Em Clark e Fincham (eds.). Critical Consulting: New Perspectives on the Management Advice Industry. Blackwell, Oxford, pp. 21-27.

Kurb, M. (1996). Management Consulting. A Guide to the Profession. Genf: International Labour Office, $3^{\mathrm{a}}$ edição (rev), Geneva.

Lopes da Costa, R. (2009). A Coordenação dos Recursos como factor de Competitividade no Setor da Banca. Tese de Mestrado, Departamento de Gestão, INDEG - ISCTE, Instituto Universitário de Lisboa, Lisboa.

Lopes da Costa, R. \& António, N. (2011). The “Outsourcing” as an Instrument of Competitiveness in the Business Consulting Industry. Journal of Management Research, 3(1) (online).

Maister, D. (1982). Balancing the Professional Service Firm. Sloan Management Review, Fall, pp. 3-13. 


\section{Macrothink}

Journal of Management Research ISSN 1941-899X 2013, Vol. 5, No. 2

Nikolova, N., Reihlen, M. \& Schlapfner, J. (2009). Client and Consultant Interaction: Capturing Social Practices of Professional Services Production: Scandinavian Journal of Management, 25(3), 289-298. http://dx.doi.org/10.1016/j.scaman.2009.05.004

Schein, E. H. (1988). Process Consultation: Its Role in Organization Development. Addison-Wesley, 2nd, 1. Reading, Mass.

Schein, E. H. (1999). Process Consultation Revisited. Addison-Wesley, Reading, Mass.

Sturdy, A J. (1997). The consultancy Process - An Insecure Business? Journal of Management Studies, 34(3), 389-414. http://dx.doi.org/10.1111/1467-6486.00056

The Economist (1997). Trimming the Fat - a Survey of Management Consultancy. The Economist (March 22).

Werr, A. \& Styhre A. (2002). Management Consultants Friend or Foe?. International Studies of Management \& Organization, 32(4), 43-66. 